исследований в практике обучения второму иностранному язику / 3. Б. Девицкая // Известия Российского государственного педагогического университета им. А. И. Герцена. - $\quad$ Выпуск $\quad$ № 51. - $\quad$ 2008. - $\quad$ С. 196-201. 5. Петрова Л. М.Использование мультимедийных средств для повышения уровня усвоения учебного материала / Л. М. Петрова // Современные технологии обучения иностранным языкам: Международная научно-практическая конференция: сб.науч. трудов / отв. ред. Н. С. Шарафутдинова. - Ульяновск : УлГТУ - 2011. - 200 с. 6. Сергсєва Г. А. Викладання іноземної мови із застосуванням мультимедійних технологій: стан та проблеми / Г. А. Сергєєва // Сучасні засоби навчання іноземних мов у вищих навчальних закладах / Національний університет «Юридична академія України імені Ярослава Мудрого»/ Упорядник: Нестеренко К. В. - Харків : НУ «ЮАУім. Ярослава Мудрого», 2013. -С. 99-101. 7. Скачкова В. В. Вплив технічних засобів навчання на результативність засвоєння іноземної мови студентами / В. В. Скачкова, А. Ю. Скачкова // Сучасні засоби навчання іноземних мов у вищих навчальних закладах / Національний університет «Юридична академія України імені Ярослава Мудрого» / Упорядник :Нестеренко К. В. - Харків : НУ «ЮАУім. Ярослава Мудрого», 2013. - 132 с. 8. Чигогидзе К. 3. Постижение значения незнакомого слова посредством контекста: автореф. дис. на соискание ученой степени канд. пед. наук / К. 3. Чигогидзе. - Тбилиси, 1990. - 21 с. 9. Taylor J. Career Paths English: Police / J. Taylor, J. Dooly // United Kingdom: Express Publishing, 2011. - 60 p.

УДК 378.011.3- 051:339.13

Анатолій Путінцев

\title{
ПРОБЛЕМИ ЗАСТОСУВАННЯ ПЕДАГОГІЧНОГО МОДЕЛЮВАННЯ У ПРОЦЕСІ ПРОФЕСІЙНОЇ ПІДГОТОВКИ МАЙБУТНІХ МАРКЕТОЛОГІВ
}

Путінцев А. В. Проблеми застосування педагогічного моделювання у процесі професійної підготовки майбутніх маркетологів.

У статті акцентовано увагу на проблемі підвищення конкурентоспроможності випускників вищих навчальних закладів, зокрема майбутніх маркетологів, досліджено теоретичні основи педагогічного моделювання, визначено види педагогічних моделей, наведено визначення і класифікацію педагогічних моделей.

Ключові слова:модель, педагогічне моделювання, професіоналізм, маркетолог, методи активного навчання.

Путинцев А. В. Проблемы применения педагогического моделирования в процессе профессиональной подготовки будущих маркетологов.

В статье акцентировано внимание на проблеме повышения конкурентоспособности выпускников высших учебных заведений, в частности будущих маркетологов, исследованы теоретические основы педагогического моделирования, определены виды педагогических моделей, приведены определение и классификация педагогических моделей.

Ключевые слова:модель, педагогическое моделирование, профессионализм, маркетолог, методы активного обучения.

Putintsev A. V. Problems applying pedagogical modeling in the process of professional training of future marketing specialists.

In the article attention is accented on the problem of increase of competitiveness of graduating students of higher educational establishments, in particular future marketing 106

Педагогіка вищої та середної школи. - 2014. - Вип. 41 
specialists, theoretical basis of pedagogical modeling are investigated, types of pedagogical models, determination and classification of pedagogical models are defined.

Key words: model, pedagogical modeling, professionalism, marketing specialists, methods active learning.

Кардинальні зміни, які відбуваються в Україні, відображаються і в системі освіти. Необхідність підвищення рівня економічної освіти потребує розроблення стратегії й тактики викладання економічних дисциплін. Оволодіння методикою проведення занять - складний і тривалий процес. Не кожен викладач, який працює у ВНЗ навіть тривалий період, володіє цим мистецтвом і проводить заняття на рівні, необхідному для досягнення максимального ефекту. Але те, що таким мистецтвом необхідно оволодівати, сумніву не підлягає.

Конкурентоспроможність випускників ВН3, зокрема майбутніх маркетологів, значною мірою залежить від того, наскільки вони опанували сучасні економічні знання, від рівня їхньої економічної культури, вміння мислити й діяти в системі ринкової економіки. Це, своєю чергою, зумовлює потребу застосування таких форм, методів, прийомів i засобів навчання, які можуть зробити навчальний процес інтенсивним, максимально активізувати пізнавальну діяльність студентів. Цьому повною мірою відповідають методи активного навчання. Такі методи навчання зумовлюють усвідомлену зацікавлену розумову діяльність студентів, активне сприйняття теоретичного матеріалу в навчальному процесі, розвиток умінь та навичок самостійного вироблення рішень із проблемних питань.

Цій актуальній науковій проблемі присвятили свої дослідження С. Архангельський, Н. Бібік, Т. Ващик, А. Дахін, О. Рудницька, Л. Фрідман та інші [114]. Наш науковий пошук полягає у з'ясуванні можливостей використання методів активного навчання під час професійної підготовки майбутніх маркетологів та розробленні педагогічної моделі забезпечення якості навчального процесу майбутніх маркетологів за допомогою активних методів навчання.

Mema cmammi- дослідити теоретичні основи педагогічного моделювання, визначити види педагогічних моделей, запропонувати визначення і класифікацію педагогічних моделей.

Слово «модель» походить від латинського «modelium», що означає «міра», «спосіб». Під моделлю в широкому сенсі розуміють структуру, створену подумки або на практиці, що відтворює частину дійсності у спрощеній наочній формі [14, с. 8]. Часто модель застосовують як синонім теорії у випадку, коли теорія ще недостатньо розроблена, у ній мало дедуктивних кроків, багато незрозумілого. Моделювання трактують як репродукування характеристики певного об'єкта на інший об'єкт, що є моделлю, спеціально створеною для їх вивчення. У процесі розвитку поняття «моделювання» підкреслюється, що метод моделей базується на аналогії функцій, які здійснюються об'єктами різної природи [1, с. 289-290]. Так, О. Рудницька розуміє модель як штучну систему, яка відображає з певною точністю властивості об'єкта, що досліджується [12, с. 212]. Крім того, моделювання трактують як дослідження об'єктів пізнання на їх моделях, а також побудову та вивчення моделей реальних явищ, а модель - як уявлювану або матеріально реалізовану систему, що відображає або відтворює об'єкт дослідження і здатна замінити його так, що іiі вивчення уможливлює виникнення нової інформації про об'єкт [10, с. 46].

Визначаючи «моделювання» як одну з основних категорій пізнання, інші автори вважають, що на ідеї моделювання грунтується будь-який метод наукового дослідження - як теоретичний, при якому використовуються різноманітні знакові, 
абстрактні моделі, так і експериментальний, що використовує предметні моделі [2, c. 323, c. 392]. На наш погляд, найбільш повне визначення поняття «модель» дає В. Штофф у своїй книзі «Моделювання та філософія»: «Під моделлю ми розуміємо таку систему, що уявляється в думках або матеріально реалізується, яка, відображаючи чи відтворюючи об'єкт дослідження, здатна заміщувати його так, що вивчення цієї системи дає нам нову інформацію про цей об'єкт» [14, с. 22].

Отже, аналіз сучасних досліджень дає підстави для тлумачення поняття «моделювання» як науково-пізнавального методу дослідження змістових, технологічних, організаційних компонентів навчально-виховного процесу шляхом їх абстраговано-раціонального створення, вивчення й реалізації.

Система навчального процесу, яка створює сучасну модель навчання,- це цілісна множина сукупності iï основних складників. Об'єктами дидактичного моделювання є природні та штучні системи, а суб'єктом - сама людська свідомість.

I. Зязюн і Г. Сагач [7] на основі гуманістичної парадигми освіти визначають такі вимоги для розроблення дидактичної моделі:

- вона має бути об'єктивною (відображати реальність);

- суб'єктивною (відображати об'єкт з урахуванням тезаурусу реципієнта);

- нормативною (відображати бажане);

- інтерактивною (передбачати діалог зі студентом);

- адаптивною (пристосовуватись до індивідуальних особливостей людини, передусім до рівня різновидів їі досвіду);

- відкритою (передбачати проектно-технологічну нормотворчість діяльності реципієнта).

Модель навчального процессу - це еталонне уявлення про навчання учнів, його конструювання в умовах конкретних освітньо-виховних закладів. Вона визначає цілі, основи організації та проведення навчального процесу.

Основними іï складниками мають бути цільовий, стимулювально-мотиваційний, змістовий, процесуальний, контрольно-регулювальний, оцінково-результативний, суб'єкт-суб'єктний компоненти. Особистісну спрямованість цій моделі надають гуманізація, гуманітаризація i демократизація названих складників, а щодо процесуального компонента - формування суб'єктно-суб' єктних взаємин між педагогом і учнем - учень може і повинен бути суб'єктом навчання. Альтернативи тут немає.

М. Каган виокремлює три характеристики суб'єкта: перша (вихідна і головна) його активність на противагу пасивності або реактивності об'єкта; друга - свідомий і самосвідомий характер цієї активності, що сприяє цілеспрямованій i вільній діяльності; третя - його унікальність. Учень спроможний стати суб'єктом власного учіння (тією мірою, якою він володіє особистісними якостями). Перетворення учня на суб'єкт і є процесом виховання, становлення особистісних якостей, прилучення учня до інших людей i його відособленням від інших, його соціалізацією та самоствердженням. «Людина $\epsilon$ нічим іншим, як тим, що вона сама із себе робить»,сказав про це Ж.-П. Сартр.

На жаль, в основу тільки окремих сучасних концепцій навчання чи дидактичних систем покладено визнання ролі учня як головної постаті навчального процесу. До цих систем, першою чергою, належать педагогіка співробітництва, гуманістична педагогіка, особистісно зорієнтоване навчання. Німецький соціолог К. Манхейм влучно зауважив, що людина може стати особистістю для самої себе тільки тією мірою, якою вона стала особистістю для інших, а інші є особистостями для неї.

Знання й осмислення основних компонентів дидактичного процесу надають 
змогу педагогові передбачити конкретний варіант дидактичної системи, глибше зрозуміти сутнісну характеристику навчання як педагогічного явища, науково обгрунтувати підходи до його практичного здійснення, прогнозувати результати реалізації. Розуміння того, що таке моделювання, тільки оформлюється в педагогічній науці, але воно вже посідає важливе місце поруч з такими методами пізнання, як спостереження та експеримент. На педагогічному моделюванні грунтується проектування освітніх процесів. Поєднання проектування і моделювання виводить педагогічне дослідження на рівень загальнонаукової методології. У середині XX ст. осмислення досвіду окремих наук, зокрема кібернетики та лінгвістики, привело до спроб застосувати моделювання в розв'язанні педагогічних проблем. Моделювання у педагогіці безпосередньо пов'язане 3 визначальною роллю наочності у процесі пізнання загалом і реалізацією принципу наочності в навчанні.

Значний внесок у справу педагогічного моделювання зробив Л. Фрідман. На його думку, моделювання $\epsilon$ навчальною дією i засобом, без якого не можливе повноцінне навчання [13]. Таке тлумачення було досить розповсюджене у психологопедагогічній літературі періоду 80-90-х років. На початку XXI ст. моделювання активно запроваджується у всіх галузях педагогічної науки. Найчастіше педагогічне моделювання визначають як штучно створений зразок, спеціальну знаковосимволічну форму, що використовується для відображення і відтворення в дещо простішому вигляді структури багатофакторного явища, безпосереднє вивчення якої дає нові знання про об'єкт дослідження. Об'єктом моделювання стають освітні процеси, на які розповсюджується теоретичне педагогічне моделювання, що збагачується і розвивається на основі узагальнення освітньої практики, врахування іiі потреб і проблем. Необхідно зазначити, що розуміння понять «педагогічна модель» та «педагогічне моделювання» педагогами і методистами характеризується значною варіативністю. Так, М. Панфілов зауважує, що педагогічна модель $є$ логічно

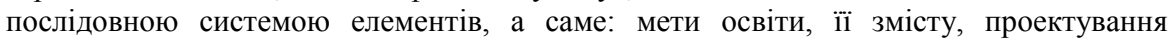
педагогічних технологій та технологій керівництва освітнім процесом, побудови навчальних планів і програм [11].

Т. Ващик педагогічну модель визначає як будь-яку ідею, організацію, здійснення та розвиток педагогічного об'єкта. До таких моделей належать: концепції розвитку навчальних закладів, статути і положення навчальних закладів, педагогічні теорії тощо [5]. На думку інших наукоців, процес педагогічного моделювання - це послідовне розроблення серії моделей, що змінюють одна одну в міру наближення до об’єкта, що моделюється. На методологічному рівні педагогічне моделювання передбачає концептуальні положення, що відбивають його мету та понятійний апарат. На теоретичному рівні представлені педагогічні моделі, на методичному - алгоритм їх застосування. Відповідно, визначають три групи педагогічних моделей: концептуальну (головна ідея, що визначає зміст, структуру і новизну підходу); дидактичну (грунтується на традиційних класичних положеннях та принципах, відбиває дослідницькі підходи до моделювання, новизну, що розкривається в ході дослідження автором); методичну (характеризується конкретними фактами та фрагментами навчальної діяльності, ії змістом).

В. Лобашев теж зазначає, що педагогічні моделі належать до класу не строго описаних систем. Моделювання таких систем потребує ретельного попереднього опису i схематизації внутрішніх процесів, визначення граничних умов впливу зовнішнього середовища, максимально повного спрощення алгоритму взаємодії всіх частин [9]. О. Дахін розглядає «педагогічне моделювання» як концептуальний підхід 
до розв'язання педагогічних завдань, що полягає в поєднанні всіх знань про людину. Він розглядає таке моделювання як засіб модернізації теоретичних засад педагогіки. На його думку, застосовуючи методологію моделювання явищ різної природи, можна побудувати теоретичне підгрунтя педагогічного моделювання, яке матиме цілісність, повноту та буде адекватно описувати відомі педагогічні явища в умовах невизначеності [6]. Згідно 3 думкою І. Ліпського, педагогічна модель - це спрощений зразок об'єкта педагогічної практики, що зберігає лише його найсуттєвіші риси. Педагогічна модель повинна задовольняти певні вимоги: об'єктивно відповідати модельованому об'єкту педагогічної практики; мати здатність замінити його певною мірою; iї можна було б інтерпретувати в термінах педагогіки [8]. Проблема застосування моделювання у педагогіці складна і недостатньо розроблена. Формалізація педагогічних знань - одна $з$ галузей педагогіки, яка вимагає інтенсивного вивчення, основою якого $є$ дослідження, що ведуться в предметних галузях дидактики. Досліджуючи проблему впровадження педагогічного моделювання, використовували теоретичні розробки та матеріали практики, методики навчання маркетингу.

На основі теорії педагогічного проектування виокремлюють такі функціональні види педагогічних моделей: прогностична модель (для оптимального розподілу ресурсів), концептуальна модель (заснована на програмі дій та базі даних), інструментальна модель (за допомогою якої вчителі можуть опанувати дидактичні інструменти), моніторингова (для виявлення зворотного зв'язку і корекції можливих відхилень від запланованого результату) та рефлексивна (для вироблення рішень у разі виникнення непередбачуваних ситуацій). Ураховуючизазначене вище, на основі аналізу робіт вітчизняних і зарубіжних педагогів, ми визначили види педагогічних моделей. За об'єктом моделювання, на наш погляд, можна виокремити такі основні види педагогічних моделей: освітні моделі, моделі науково-педагогічної діяльності, моделі навчання та навчальні моделі.

Освітні моделі - це логічно послідовні системи елементів, що передбачають мету освіти, іiі зміст, проектування педагогічних технологій і технологій управління освітнім процесом, структуру освітнього процесу, навчальні плани i програми. Так, Н. Петрова [5] запропонувала освітню модель змісту шкільної географічної освіти, в основу якої покладено просторово-часову парадигму географічної оболонки, географічного середовища та чинників, що іï формують i змінюють. Різновидами освітніх моделей $\epsilon$ освітньо-організаційні, моделі процесу навчання, моделі прогресивногопедагогічного досвіду, моделі авторських педагогічних технологій (технологічні моделі), методичних систем та концептуальні моделі уроків. Зупинимося на освітньо-організаційних моделях (ООМ). Кожний освітній заклад характеризується своєю ООМ. Так, особливістю поточної ООМ є предметно-класне навчання у рівневих потоках, в які можуть входити кілька класів. Селективно-групова ООМ полягає у предметному навчанні в рівневих групах в одному класі 3 деяких предметів. Модель змішаних здібностей - у створенні тимчасових груп за когнітивними ознаками. Інтегративна модель - класи з багатоваріантними можливостями для індивідуальної роботи. Інноваційна модель - формуються групи змішаних здібностей, ураховуються кілька критеріїв. В одному освітньому закладі може впроваджуватись кілька різних ООМ.

В. Пікельна у своєму фундаментальному дослідженні проблем моделювання управління навчальними закладами розглядає ООМ як складну систему, що має свої принципи, зміст і форми вияву, методику реалізації.

Вона визначила такі методологічні принципи ООМ: 
- системно-структурний підхід;

- прогнозування діяльності;

- урахування закономірностей процесу управління й усунення суперечностей.

До теоретичних принципів ООМ авторка відносить такі:

- розмежування цілей керівництва й мети управління;

- розподіл функцій управління;

- послідовність моделювання системи управління і подальшого моделювання іiі підсистем [5].

Моделювання прогресивного педагогічного досвіду (ППД) - це цілеспрямована науково-методична діяльність науковців-педагогів, працівників методичних служб і керівників освітніх закладів, які 3 урахуванням таких чинників, як соціальна спрямованість, морально-психологічні, науково-теоретичні, науково-методичні та правові чинники, забезпечують науково обгрунтоване розроблення відповідних моделей ППД. Так, наприкінці 80 -х років минулого століття київськими педагогами під керівництвом професора М. Красовицького створена і реалізовувалась на практиці теорія прогнозування та моделювання ППД. Під моделлю методичної системи вчителя розуміють іiі відображення, що описує формальною мовою компоненти системи, взаємозв'язки між ними, а також перетворень, становлення і розвитку цієї системи в реальних умовах соціокультурного середовища.

Моделювання авторської педагогічної технології- це виключно наукове проектування процесу навчання, що складається 3 чіткого переліку етапів, під час виконання яких досягається запрограмований результат. Технологічні моделі навчання спрямовані на досягнення практично всіма учнями наперед заданих результатів на рівні гарантованого мінімуму, який забезпечується стандартизованим контролем і корекцією поточних результатів навчання. Продуктивні (пошукові) моделі мають процесуально зорієнтований характер і спрямовані на засвоєння учнями нового досвіду, який вони конструюють самостійно. До них належать: моделі навчання як організація систематичної дослідницької діяльності; моделі навчання як організація навчальноігрової, моделювальної діяльності; моделі навчання як організація комунікативнодіалогової діяльності, активного обміну думками, творчої дискусії. Моделі уроків, у розроблення яких значний внесок зробили І. Підласий та В. Бондар [4], мають концептуальний характер. Моделюванню підлягають як окремі етапи уроку, так і його структура. Останнім часом у педагогічній літературі актуальним предметом обговорення стали дидактичні функції підручника та його моделі. В. Максаковський, зокрема, аналізує особливості європейських та американських підручників.

Широке розповсюдження методу моделювання в педагогічних дослідженнях пояснюється різноманітністю його гносеологічних функцій. Педагогічне моделювання полягає у вивченні педагогічних явищ і процесів на спеціальному об'єкті - моделі, що є проміжною ланкою між суб'єктом - педагогом-дослідником і предметом дослідження - певних властивостей та відношень між елементами навчального процесу. Така модель $є$ продуктом аналізу елементів навчання:

1) педагогічної діяльності вчителя;

2) навчальної діяльності учня;

3) змісту навчання (певного набору знань про природу, суспільство, досвід творчої діяльності та емоційно-почуттєвий досвід);

4) форм організації навчання;

5) методів навчання;

6) засобів навчання; 
7) засобів контролю навчальної діяльності та оцінювального інструментарію.

Отже, моделювання як метод наукового дослідження дозволяє поєднати емпіричне i теоретичне в педагогічному дослідженні. Емпіричний рівень спостережень - пряме спостереження, експеримент, факти практики. Теоретичний побудова логічних конструкцій і наукових абстракцій. Отже, моделювання як засіб дослідження сприяє переведенню безсистемних знань у систему і має аналізуючі та синтезуючі функції. До основних етапів педагогічного моделювання належать: постановка завдання (мети), вибір або створення моделі, вивчення моделі, змістова інтерпретація результатів дослідження. Основна вимога до такої моделі: простота i адекватність. На основі обраної моделі проводиться педагогічний експеримент задля вивчення iї ефективності. Результати експерименту обробляються за допомогою статистичного методу. Під час оброблення результатів дослідження вибирається математична модель представлення педагогічного явища 3 урахуванням його специфіки. Практична та пізнавальна цінність такого моделювання полягає в адекватності аспектам об'єкта, що вивчається, та врахуванні принципів моделювання: наочності, визначеності, об'єктивності.

\section{Література}

1. Архангельский С. М. Лекции по теории обучения в высшей школе / С. М. Архангельский. - М. : Высш. шк., 1974. - 384 с. 2. Белл Д. Грядущее постиндустриальное общество. Опыт социального прогнозирования / Даниел Белл. M. : Academia, 2004. - 944 с. 3. Бібік Н. Компетентнісний підхід у презентації освітніх результатів / Н. Бібік // Школа першого ступеня: теорія і практика: зб. наук. праць Переяслав-Хмельницького держ. пед. ун-ту ім. Григорія Сковороди. - Вип. 10.Переяслав-Хмельницький, 2004. - С. 157-163. 4. Бондар С. П. Компетентність особистості - інтегрований компонент навчальних досягнень учнів / С. П. Бондар // Біологія і хімія в школі. - 2003. -№ 2. - С. 8-9. 5. Ващик Т. І. Моделювання у навчально-виховному процесі вищої школи / Т. І. Ващик // Нові технології навчання. К. : НМЦВО, 2005. - Вип. 41. - С. 147-158. 6. Дахин А. Н. Педагогическое моделирование: сущность, эффективность и неопределенность / А. Н. Дахин // Школьные технологии. - 2002. - № 2. - С. 62-67. 7. Зязюн І. А. Краса педагогічної дії:[навч. посібн.] / І. А. Зязюн. - К. :Українсько-фінський інститут менеджменту і бізнесу, 1997. - 302 с. 8. Липский И. А. Социальная педагогика: Методологический аналіз: [монографія] / И. А. Липский. - М. : Сфера, 2004. - 320 с. 9. Лобашев В. Д. Структурный подход к моделированию ведущих элементов процесса обучения/ В. Д. Лобашев // Инновации в образовании. - 2006. - № 3. - С.99-111. 10. Макєєва I. В. Роль семінарського заняття у підготовці фахівця і методика управління дискусією / І. В. Макєєва // Радянська педагогіка. - М. : Освіта. - 2003. - № 5. - С. 61. 11. Панфілов М. А. Знаково-символическое моделирование учебной информации в вузе / М. А. Панфилов // Педагогика. - 2005. - № 9. - С. 51-56. 12. Рудницька О. П. Педагогіка загальна та мистецька:[навч. посібн.] /О. П. Рудницька. - К. : Інтерпроф, 2002. - 270 с. 13. Фридман Л. М. Наглядность и моделирование в обучении / Л. М. Фридман. - М. : Знание, 1984. - 80 с. 14. Штофф В. А. Моделирование и философия / В. А. Штофф. - М. : Наука, 1996. - 304 с.

УДК 377.131 .14

Тетяна Сердюк

\section{НЕГАТИВНІ ЧИННИКИ ЗАСТОСУВАННЯ ГРУПОВИХ ФОРМ ОРГАНІЗАЦЇ̈ НАВЧАЛЬНО-ПІЗНАВАЛЬНОЇ ДІЯЛЬНОСТІ СТУДЕНТІВ}

Сердюк Т. В. Негативні чинники застосування групових форм організації навчально-пізнавальної діяльності студентів. 